IZA DP No. 8459

Ireland's Recession and the Immigrant/Native Earnings Gap

Alan Barrett

Adele Bergin

Elish Kelly

Séamus McGuinness

September 2014 


\title{
Ireland's Recession and the Immigrant/Native Earnings Gap
}

\author{
Alan Barrett \\ Economic and Social Research Institute \\ and IZA \\ Adele Bergin \\ Economic and Social Research Institute \\ Elish Kelly \\ Economic and Social Research Institute
}

Séamus McGuinness

Economic and Social Research Institute and IZA

\section{Discussion Paper No. 8459 \\ September 2014}

\author{
IZA \\ P.O. Box 7240 \\ 53072 Bonn \\ Germany \\ Phone: +49-228-3894-0 \\ Fax: +49-228-3894-180 \\ E-mail: iza@iza.org
}

Any opinions expressed here are those of the author(s) and not those of IZA. Research published in this series may include views on policy, but the institute itself takes no institutional policy positions. The IZA research network is committed to the IZA Guiding Principles of Research Integrity.

The Institute for the Study of Labor (IZA) in Bonn is a local and virtual international research center and a place of communication between science, politics and business. IZA is an independent nonprofit organization supported by Deutsche Post Foundation. The center is associated with the University of Bonn and offers a stimulating research environment through its international network, workshops and conferences, data service, project support, research visits and doctoral program. IZA engages in (i) original and internationally competitive research in all fields of labor economics, (ii) development of policy concepts, and (iii) dissemination of research results and concepts to the interested public.

IZA Discussion Papers often represent preliminary work and are circulated to encourage discussion. Citation of such a paper should account for its provisional character. A revised version may be available directly from the author. 
IZA Discussion Paper No. 8459

September 2014

\section{ABSTRACT}

\section{Ireland's Recession and the Immigrant/Native Earnings Gap ${ }^{1}$}

The economic collapse was more severe in Ireland relative to elsewhere. Many questions have arisen concerning the impacts of the collapse, including the impacts on immigrants and their subsequent reactions. Previous research shows that immigrant employment contracted sharply over the recession, thereby suggesting reduced demand for immigrant labour. In this paper, we ask whether immigrants' earnings also fell, relative to natives. Although the raw data shows a widening of the immigrant/native pay gap, when we control for relevant characteristics the adjusted wage gap narrows. A decomposition analysis shows that most of the change in the raw wage gap is generated by the changing composition of the immigrants who were employed.

JEL Classification: J61

Keywords: Ireland, recession, immigrant earnings

Corresponding author:

Alan Barrett

Economic and Social Research Institute

Whitaker Square

Sir John Rogerson's Quay

Dublin 2

Ireland

E-mail: alan.barrett@esri.ie

\footnotetext{
${ }^{1}$ The authors thank the anonymous referee as well as the editors of this volume for providing a number of suggestions that helped to improve the chapter significantly. We also thank participants at a workshop in the Central European University, Budapest, in October 2012. We remain responsible for any mistakes still present.
} 


\section{Introduction}

Since the mid-1990s, the Irish economy has experienced large periods of growth and contraction by international and historic standards. In Figure 1, we show rates of growth in real GDP and real GNP for the period 1996 to 2011, clearly highlighting the contrasting performance of the Irish economy over the period. In the mid- to late-1990s, the Irish economy grew at annual rates in the region of 10 per cent, before growth moderated in the early years of the 2000s, with annual rates of growth around 5 per cent meaning that Ireland's economic performance still looked remarkably healthy. However, when the global crisis of 2007/8 emerged, the Irish economy proved extremely vulnerable.

Figure 1. Rates of growth in Ireland's real GDP and real GNP, 1996 to 2011

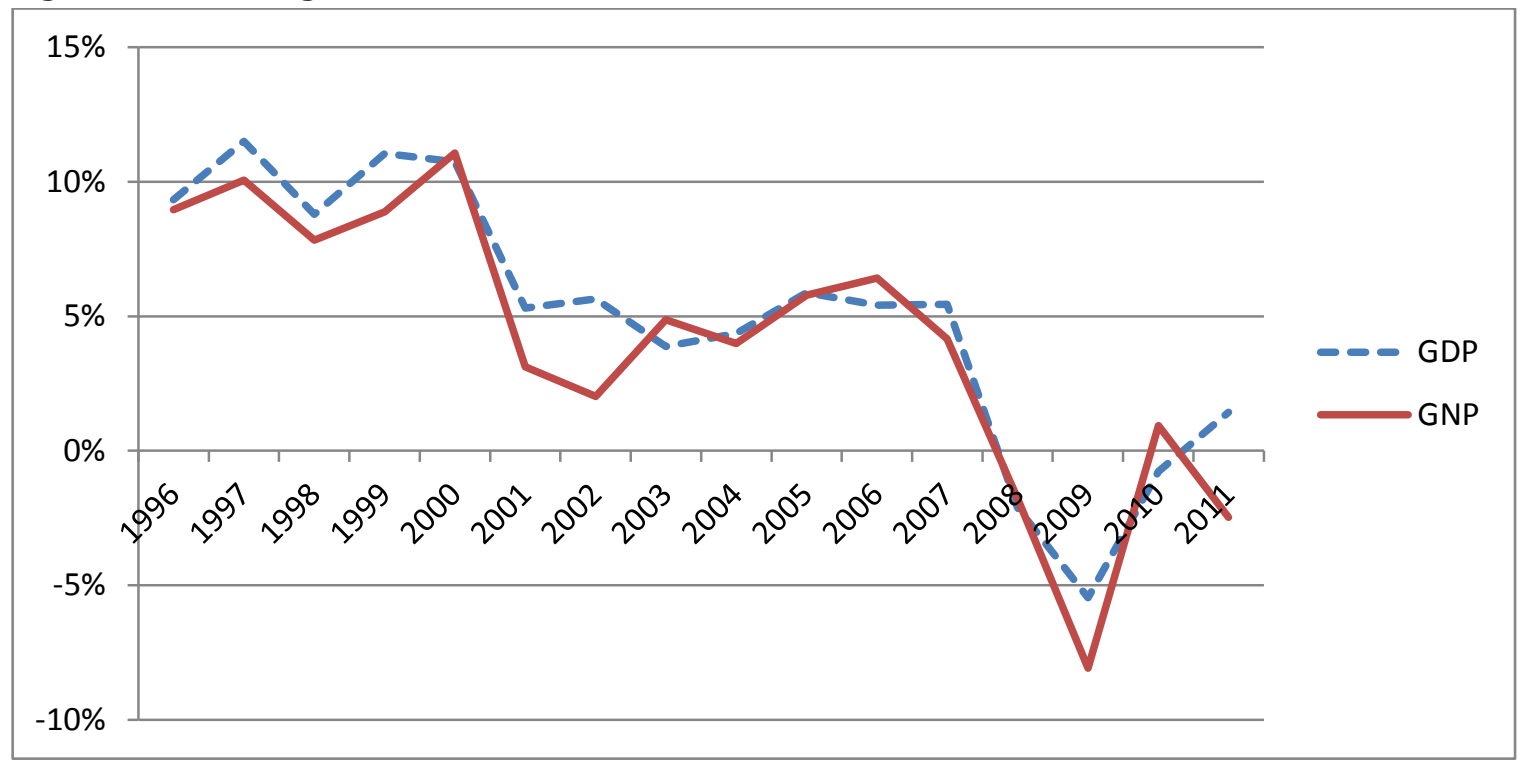

Source: Central Statistics Office

The international financial collapse had a severe effect on Ireland, partly owing to the existence of a property price bubble and excessive bank lending into the property sector. As shown in Figure 1, Ireland's real GDP fell each year between 2008 and 2010, by 2 per cent, 5 per cent and 1 per cent, respectively. Indeed, the decline was even more pronounced when considered in terms of GNP, with the economy contracting by 8 per cent in 2009 alone based on this measure. The economic collapse led to a severe contraction in tax revenues, partly due to an over-reliance on property-related taxes (Addison-Smyth and McQuinn, 2010). When 
combined with the banking-related liabilities that the state accrued because of the banking guarantee, a public finance crisis emerged and led to the EU/IMF bailout in 2010.

The dramatic movements in Ireland's economy have been mirrored in the migratory movements into and out of Ireland. In Figure 2, we present rates of net inflows (in thousands) over the period 1987 to 2012. Although the height of the economic boom occurred in the late1990s, the surge in inward migration is observed in the period after 2004. The main reason for this was the EU enlargement in 2004, along with the fact that Ireland was among only three countries that allowed citizens of the New Member States (NMS) full access to its labor market from May 1, 2004. In 2007, net inward migration peaked at over 100,000, representing 2.4 per cent of Ireland's population, measured at 4.2 million in 2006.

Figure 2 also shows that the economic crisis has led to a reversal of net migration. In the year ending April 2012, the net outflow was over 34,000, which in absolute numbers means that the rate of net outflow is now approaching that of the late-1980s, when Ireland last experienced large net population outflows.

Figure 2. Net inflows into Ireland (in thousands), 1987 to 2012

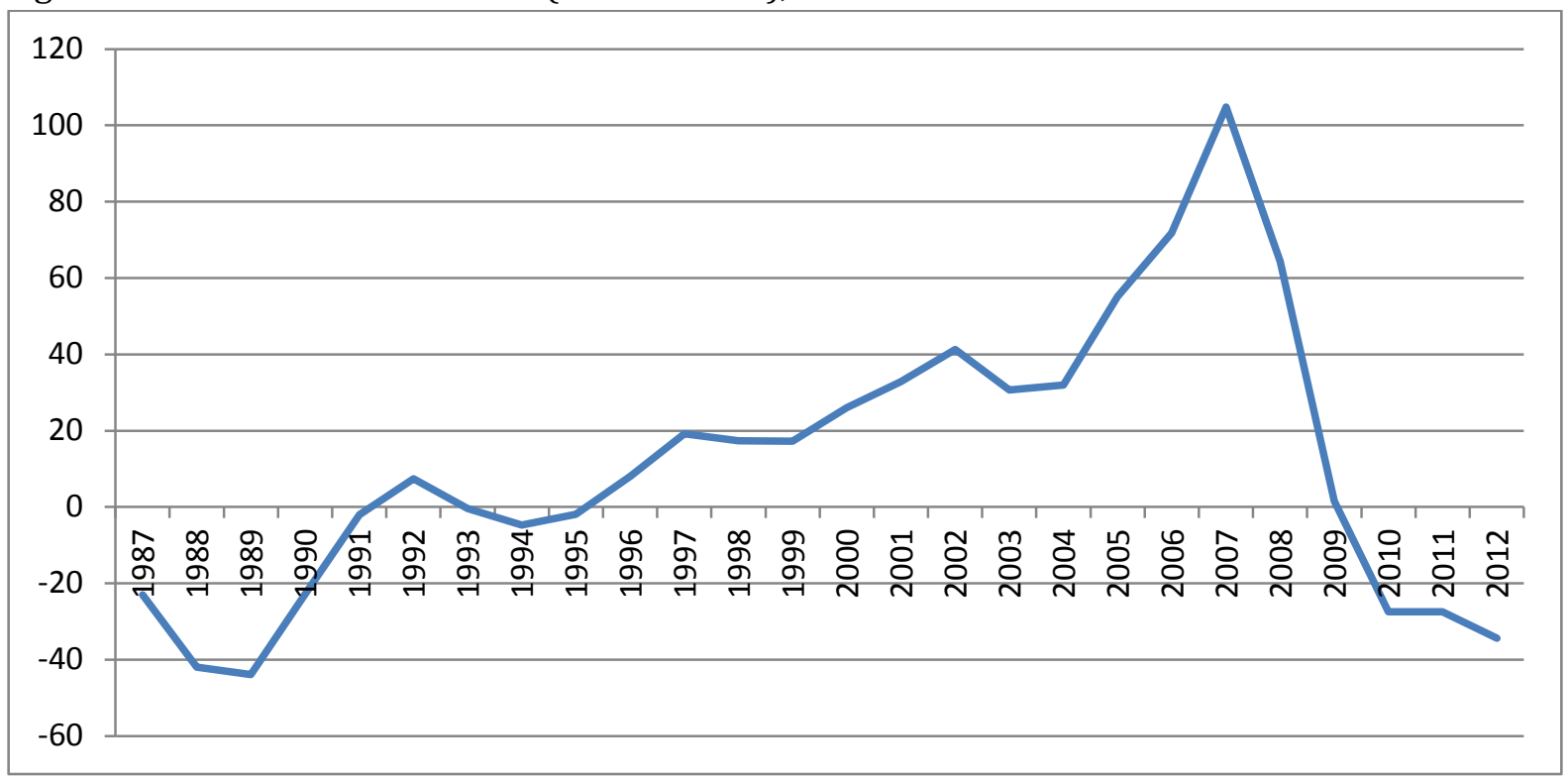

Source: Central Statistics Office 
In this chapter, we will take a closer look at migration to and from Ireland over the recent past. In Section 2, we will discuss the research findings that arose from the work conducted during the boom. Given that some of this work has been discussed in detail elsewhere, for example in Barrett (2010), we will focus on the broad findings here. In Section 3, we will present some findings on the employment outcomes of immigrants in Ireland over the crisis, highlighting that immigrants suffered high rates of job losses over the crisis relative to natives. While we know from previous work that the employment of immigrants fell over the crisis, we do not know what happened to their earnings relative to natives. Accordingly, Section 4 contains an analysis of the evolution of the immigrant-native wage gap between 2006 and 2009, the year of the deepest contraction.

\section{Immigration into Ireland during the boom}

During the mid- to late-2000s, the migration-related research agenda pursed by economists in Ireland followed that which had been pursued by economists in traditional immigrant receiving countries. As a result, the key questions addressed were as follows: what was the immigrant/native wage gap; did immigrants assimilate in terms of labor market outcomes; and what were the impacts of immigrants on native wages, employment and the public finances?

The main papers on the immigrant/native wage gap were those of Barrett and McCarthy (2007) and Barrett et al. (2012), both of which revealed the familiar finding that immigrants generally earned less than natives, even when accounting for characteristics such as age and education. Based on data from the Irish component of the EU Survey on Income and Living Conditions (EU-SILC) 2004, Barrett and McCarthy (2007) found that immigrants earned 18 per cent less than comparable natives. However, this figure concealed large differences across immigrant groups. For instance, while there was no difference in the earnings of natives and immigrants from English-speaking countries, there was a 45 per cent difference between natives and immigrants from the New Member States of the EU. 
Barrett et al. (2012) used a much larger dataset from 2006 (the National Employment Survey) to again consider the immigrant/native wage gap and expand the analysis. They also found a wage gap between natives and immigrants from the NMS, although their 18 per cent estimate was lower than that in Barrett and McCarthy. Furthermore, Barrett et al. (2012) also showed that the wage gap differed across the earnings distribution. Using quantile regressions, they found no difference in earnings at the lower end of the distribution yet large differences at the higher end. In respect of these findings, they suggested that the immigrant wage disadvantage was more likely to result from a failure to achieve comparable rates of return on human capital for higher skilled immigrants, as opposed to discrimination and exploitation at the lower end of the labor market.

Barrett and Duffy (2008) was the only paper to directly address the question of assimilation in the labor market. The authors used data from the quarterly national labor force survey and explored whether immigrants who had been longer in Ireland had better occupational outcomes, finding evidence of an "occupational gap" for immigrants: while immigrants in Ireland were relatively well-educated, the occupations in which they were employed did not fully reflect this. No evidence was found for a relationship between in the size of the occupational gap and time spent in Ireland. Accordingly, Barrett and Duffy (2008) concluded that they were unable to find evidence of labor market assimilation.

The most comprehensive study of the effects of immigration on the Irish economy was contained in Barrett et al. (2006). In this paper, the authors used a structural model of the Irish labor market and the macro-economy to simulate the impact of immigration on wages, employment and output, along with a range of other variables. Based on the assumptions underpinning the model, the study suggested that immigration had increased GDP and GDP per capita during the late-1990s and early-2000s. The mechanism within the model through which this occurred was noteworthy given that immigration was assumed to dampen wage pressures. This would have played an important role in the Irish economy in the early-2000s, 
because costs were rising and competitiveness was falling. Given the importance of external demand to a small open economy such as Ireland, competiveness is a key driver of growth. Without immigration on the scale experienced during the boom, it is argued that wages would have risen, thereby choking off labor demand and curtailing economic growth.

The analysis of Barrett et al. (2006) and others might have contributed to a generally favorable assessment of the impacts on immigration in Ireland, as further supported by the findings of Barrett and McCarthy (2007), Barrett and McCarthy (2008) and Barrett et al. (2013), where the research question related to welfare receipt on the part of immigrants. In many countries, a negative sentiment towards immigrants appears to have been voiced in recent times, partly through expressions of concern about the relatively intensive use of welfare payments and services on the part of immigrants. The results in the aforementioned studies showed that immigrants in Ireland were less likely to be in receipt of welfare payments. This observation was likely to have reflected the result of policy, at least to some degree. At the time of EU enlargement, the Irish government created a residency requirement for the receipt of welfare payments, which essentially meant that people would have to have been resident in Ireland for at least two years before eligibility for welfare applied.

In summary, the research conducted on immigration into Ireland during the boom produced a picture of immigration that was positive for Ireland. Even though immigrants might have dampened wage pressures, wages were still rising over this period and unemployment was low, with the economy appearing to absorb immigrants with minimal disruption. The only concerns related to the immigrants themselves, especially those for the NMS, given that their wages were well below those of comparable natives, partly reflecting a failure to access occupations that fully utilized their human capital. This would not be a concern if any initial disadvantages in the labor market reduced with time spent in Ireland, yet no such evidence of assimilation existed. 


\section{What happened to immigrant employment during the crisis?}

As the economic crisis began to take hold in Ireland in $2007 / 8$, Ireland's immigrant population, especially those from the NMSs, was composed of many recently arrived immigrants. As shown in Figure 2 above, immigration had surged in the mid-2000s, and while some immigrants had arrived in the 1990s and before, there was now a huge group of new arrivals. We also know from the research on labor market outcomes that many of the immigrants from the NMS were in lower earning and less-skilled jobs. These features of the immigrant population in Ireland suggested that they might be vulnerable in an economic downturn, which indeed proved the case.

In Figure 3, we show annual rates of employment change in recent years for Irish nationals and immigrants from the NMS. First, considering the earlier part of the figure, phenomenal growth in immigrant employment up to Q3 2007 can be observed, with the annual rate of employment growth for this group almost 40 per cent at that time. By contrast, there was barely any growth in the employment of Irish natives, thereby demonstrating the importance of immigration to growth in Ireland at that time.

As shown in Figure 1 above, 2009 marked the most severe contraction in GDP, which is reflected in Figure 3 in terms of reduced employment. However, there was a large difference between the reduced employment rates of Irish natives and immigrants from the NMS: while native employment fell by 8 per cent in the year to Q3 2009, the corresponding figure was 18 per cent for the NMS, and 12 per cent for all immigrants. Hence, the rate of employment loss generally among immigrants exceeded that of natives, but the rate of loss was highest for the immigrants from the NMS. In 2010, the rate of employment loss eased yet remained high, likewise the differential between natives and immigrants from the NMS. For Irish natives, employment loss was 3 per cent to Q3 2012; the corresponding number for MNS immigrants was 11 per cent. For immigrants in general, the rate of employment loss to Q3 2012 was 8 per cent. 
The numbers from the NMS who were employed in Ireland peaked at 175,000 in Q1 2008, representing over 8 per cent of those employed. By Q1 2011, the number employed had fallen to 121,000 , a decline of over 30 per cent. As a proportion of those employed, the Q1 2011 figure was 6.6 per cent.

Figure 3. Annual rates of employment change, Irish and EU NMS nationals, Q3 2007 to Q3 2012

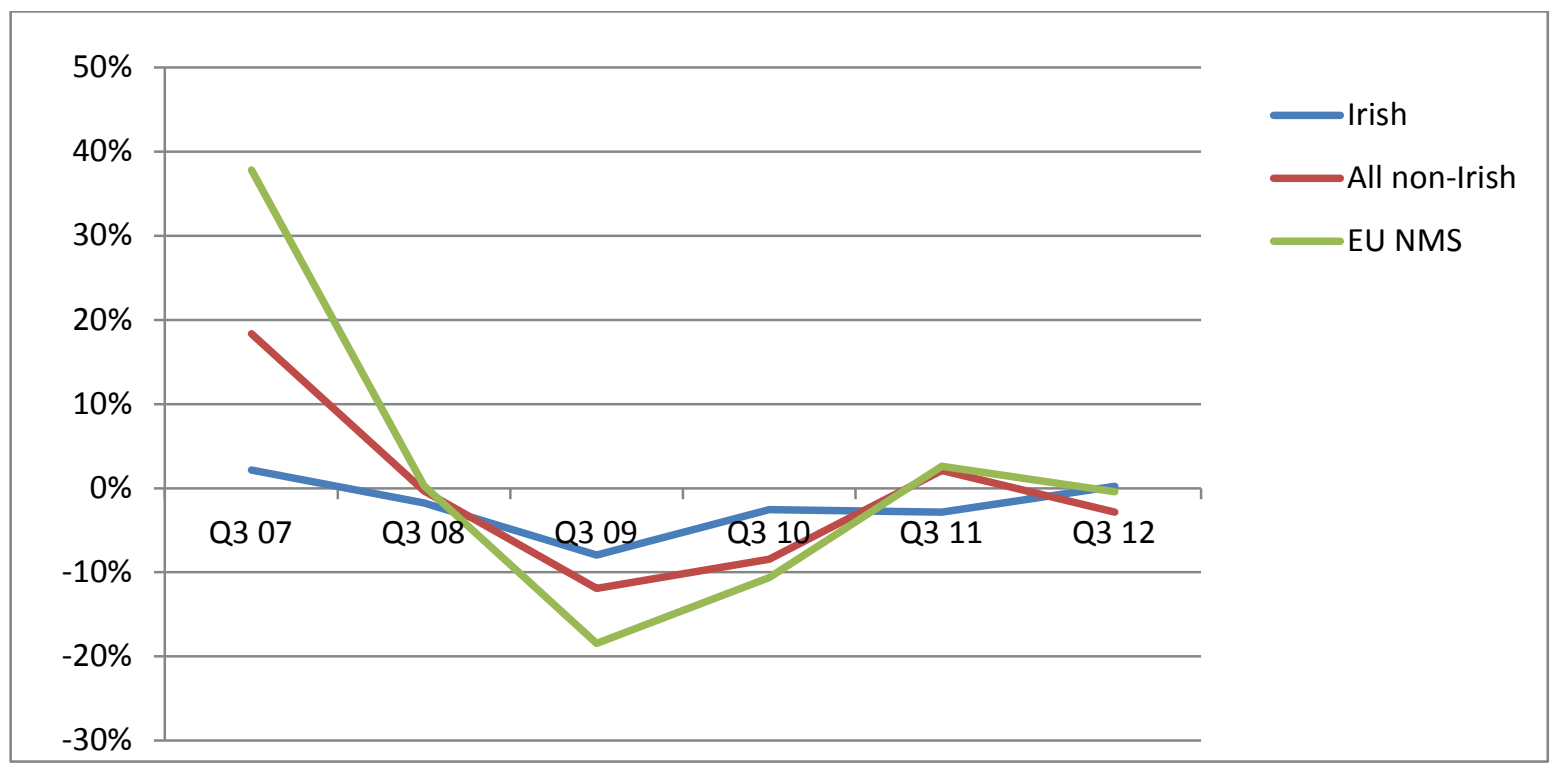

Source: Central Statistics Office

Barrett and Kelly (2012) presented this huge fall in the employment of immigrants generally, and the NMS immigrants in particular. In their paper, they also used micro-data from 2008 and 2009 to explore whether the employment fall was truly the result of immigrants' status, as opposed other characteristics that could be correlated with being an immigrant, such as age and the sector of employment. Their results confirmed that immigrants were disproportionately impacted upon by the recession, with immigrants from the NMS being most severely affected.

The employment losses experienced by both immigrants and natives, as shown in Figure 3, are clearly related to the net outflows shown in Figure 2 above. In that figure, we provide inflow and outflow numbers that capture all such movements without differentiating 
by nationality. For the year ending April 2012, the total net outflow was 34,400 . Of this total, just over 25,000 related to a net outflow of Irish nationals, with a further 4,400 being the net outflow of NMS nationals. This shows how a large proportion of the current outflow is composed of Irish nationals. However, relative to their respective populations, the outflow of NMS nationals has been large. Since 2008, when the number of nationals from the NMS living in Ireland peaked at 248,000 , the number of NMS nationals has subsequently fallen to 229,000 (a decline of almost 8 per cent). Discussions of these flows from the perspectives of the NMSs can be found in "Chapter Poland" and "Chapter Slovakia".

To summarize, Ireland's economic crisis led to large employment losses for both nationals and non-nationals, with the job losses among the NMS nationals being particularly acute. Moreover, along with the general weakness in the labor market, these job losses have led to migratory outflows. While the net outflow of Irish nationals is now the larger component of the net outflow in absolute numbers, relative to their populations resident in Ireland, the outflows are most strongly impacting upon NMS immigrants.

\section{What happened to immigrant earnings during the crisis?}

In this section, we explore what happened to the immigrant/native wage disadvantage over the crisis. Barrett and Kelly (2012) have shown that employment losses over the recession were higher among immigrants than natives, even after controlling for relevant variables such as age and education. This might indicate that labor demand for immigrants relative to natives fell, and consequently there might have been more downwards pressure on immigrant wages relative to native wages owing to the recession. As a result, we might expect the immigrant \native wage gap to have increased over the course of the recession. In addition, we know that the wage gap in 2006 was higher for more skilled immigrants (Barrett et al., 2012). Accordingly, if employment losses were concentrated among high-skilled immigrants, for whom the wage gap was higher, then this would tend to reduce the wage gap. We investigate the changes in the immigrant \native wage disadvantage over the recession using standard OLS 
wage models including variables for migrant status. Furthermore, we also examine the change in the raw wage gap by decomposing the change into observable components, i.e. changes in composition or the return(s) to particular attributes and unobservable components, in order to ascertain what is driving the change in the wage disadvantage over this period. ${ }^{2}$

\subsection{Data and methods}

The data used in this analysis are from the October 2006 and October 2009 waves of the National Employment Survey (NES), which is a cross-sectional employer-employee linked workplace survey covering both the public and private sectors, ${ }^{3}$ conducted by the Central Statistics Office (CSO). ${ }^{4}$ The employer sample is drawn from the CSO's Central Business Register, and those firms chosen are asked to select a systematic sample of employees from their payrolls: a total of 8,383 firms were surveyed in 2006 , employing 68,427 individuals, while the corresponding firm and employee figures for the 2009 survey were 9,108 and 102,208 respectively. From these samples, 4,209 $(4,753)$ firms and 51,252 $(67,907)$ employees completed their respective questionnaires in 2006 (2009), which gives a response rate of just over 50 (52) per cent from firms and 75 (66) per cent from employees. In this analysis, we focus on employees aged 15 and over, which provides us a final sample of 50,130 employees in 2006 and 66,122 in $2009 .{ }^{5}$ We apply cross-sectional weights to ensure that our results are representative of the working age employee population.

2 Walsh (forthcoming) has shown that immigrants who were in sectors covered by legally-binding labour agreements did not suffer a wage differential relative to natives in those sectors. Unfortunately, data on such agreements is not available in a comparable form across the two waves of the National Employment Survey used here. Hence, we do not control for the presence of these agreements in the analysis but possible movements into and out of the relevant sectors could influence the results. According to the figures in Walsh, just under 20 per cent of private sector employees are covered by these agreements. Our analysis includes both public and private sector workers.

3 Agriculture, forestry and fishing is the only sector that is excluded from the NES. As it is a work-place survey, the self-employed are excluded as well.

4 While the NES consists of enterprises with three or more employees, the results are calibrated to the Quarterly National Household Survey (QNHS) employment data for employees (excluding agriculture, forestry and fishing), which covers all employees.

5 Characteristic information on the sample used in the study, broken down by nationality, is available from the authors on request. 
The NES employer questionnaire captures data on employee earnings, hours worked, firm size, occupation, industry, pay agreements and company training. In the employee questionnaire, gender, age, nationality, educational attainment, employment history, professional body membership, trade union membership and other job-related characteristic (e.g. shift-work, supervisory role, flexi-time, etc.) data is gathered. The earnings information collected in the NES represents the gross monthly amount payable by the organization to its employees, in the reference month of October. ${ }^{6}$

Table 1 reports average gross hourly earnings ${ }^{7}$ for Irish employees and immigrants in 2006 and 2009, along with the hourly earnings of various immigrant groups; specifically the United Kingdom (UK), EU-15 (excluding Ireland and UK), EU--10 and EU-2 (new member states), non-EU English speaking and non-EU non-English speaking. Prior to the current recession, natives earned $€ 21.55$ per hour in 2006 , while immigrants earned less at $€ 19.52$. However, this immigrant average masks considerable variation amongst the different nationality groups. In particular, new member state employees recorded the lowest hourly earnings (€12.10 for EU-10 and €14.26 for EU-2), while non-EU non-English speaking (€23.15) and UK nationals (€22.99) had the highest. Contrary to possible expectations, natives' hourly earnings grew over the course of the recession, increasing by 7.5 per cent to $€ 23.16$ in 2009 , while immigrants' wages fell by 8.4 per cent to $€ 17.89$. Again, this immigrant average conceals differences between the nationality groupings with UK (€23.69), EU-15 (€22.44), EU-10 (€12.78) and EU-2 (€15.70) employees' hourly earnings also growing over the period, while non-EU workers' earnings fell. While this table illustrates changes in hourly earnings for natives and various immigrant groups between 2006 and 2009, the econometric analysis focuses on explaining changes in hourly earnings between Irish and immigrant workers as a whole.

6 The gross monthly measure, which is earnings before the deduction of tax, social insurance contributions and superannuation, includes i) normal wages, salaries and overtime; ii) taxable allowances, regular bonuses and commissions; and iii) holiday or sick pay for the period in question, while it excludes i) employer's PRSI, ii) redundancy payments and iii) back pay.

7 The NES data contains an hourly earnings variable, which has been derived from the gross monthly measure. 
Table 1. Average earnings per hour (€) for natives and immigrants

\begin{tabular}{|lll|}
\hline & $\mathbf{2 0 0 6}$ & $\mathbf{2 0 0 9}$ \\
\hline Irish: & & \\
Hourly Earnings & 21.55 & 23.16 \\
Sample & 43,947 & 57,875 \\
All Immigrants: & 19.52 & \\
Hourly Earnings & 6,439 & 17.89 \\
Sample & & 8,433 \\
UK & 22.99 & 23.69 \\
Hourly Earnings & 1,312 & 1,823 \\
Sample & & \\
EU15 excl. UK \& Ireland & 19.41 & 22.44 \\
Hourly Earnings & 629 & 1,097 \\
Sample & & \\
EU1O (2004 enlargement) & 12.10 & 12.78 \\
Hourly Earnings & 1,773 & 3,478 \\
Sample & & \\
EU2 (2007 enlargement) & 14.26 & 15.70 \\
Hourly Earnings & 81 & 173 \\
Sample & & \\
Non-EU, English Speaking & 21.52 & 20.83 \\
Hourly Earnings & 287 & 307 \\
Sample & & \\
Non-EU, Non-English speaking & 23.15 & 18.96 \\
Hourly Earnings & 2,357 & 1,555 \\
\hline Sample
\end{tabular}

Note: 2009 wage data is expressed in 2006 prices.

Figure 4 details the quarterly output profile, clearly showing the collapse in economic activity during 2008 to 2010, marked by 2011 Q1 real GDP (GNP) being 10 (12) per cent below its level in 2007 Q4. The two vertical lines in Figure 4 highlight the period covered by the NES data used in this study, which Bergin et al. (2012) argue encapsulates the bulk of the downturn in economic activity and therefore should capture most of the adjustment that occurred with respect to earnings. 
Figure 4. Quarterly GDP and GNP

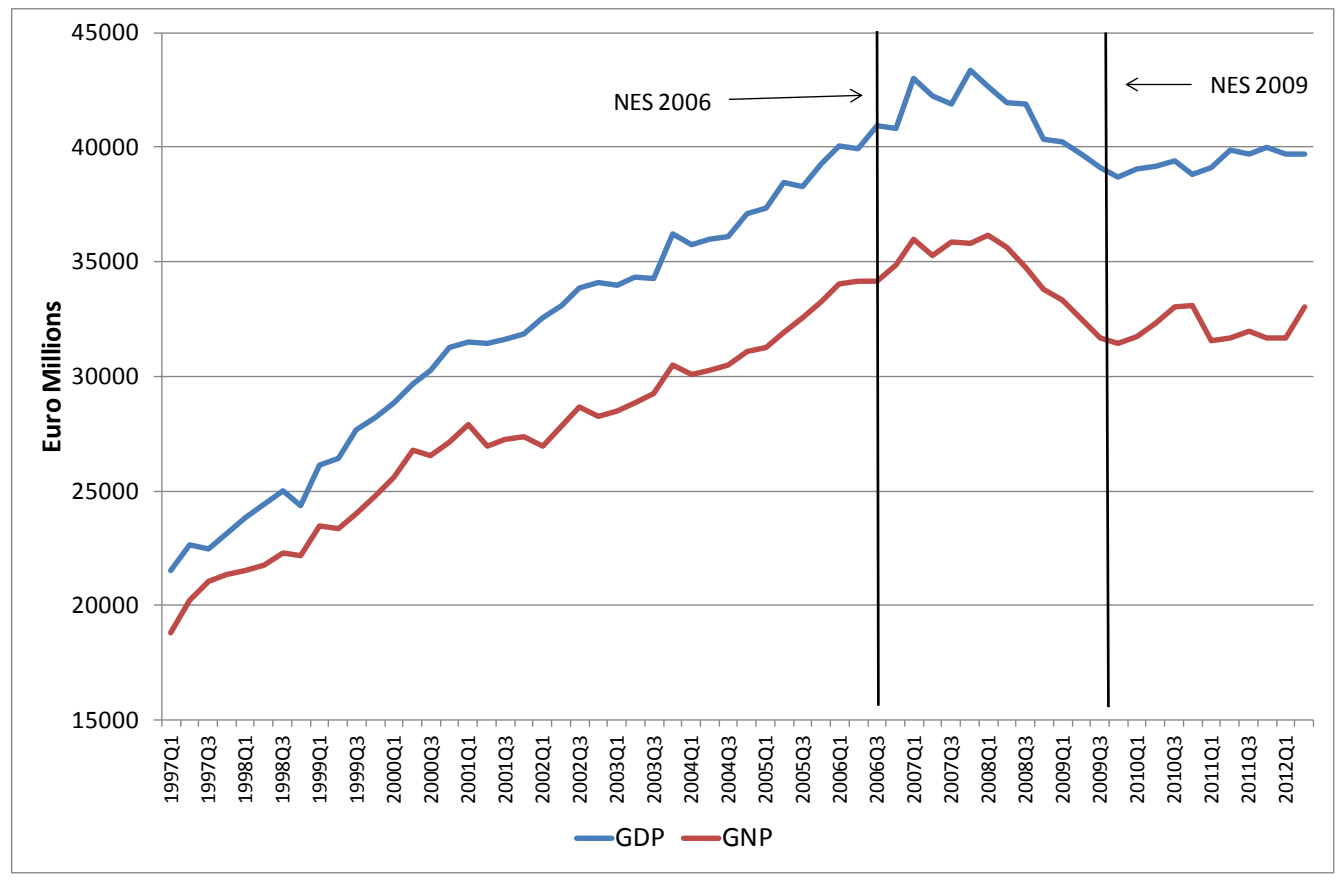

Note: Both series are seasonally adjusted and expressed in constant market prices. Source: Quarterly National Accounts, CSO.

In terms of the methodology used, we decompose the change in the immigrant \native wage gap between 2006 and 2009 using the Juhn-Murphy-Pierce methodology (JMP, 1993). This framework enables us to deconstruct changes in the wage gap over time into changes in the distribution of workers' observable characteristics (a quantity effect), variations in the returns to observed characteristics (a price effect) and changes in the distribution of residuals (an unobserved effect).

We can write the standard Mincerian wage equations for natives and immigrants as follows:

$$
\begin{gathered}
\log w_{N}=X_{N} B_{N}+\varepsilon_{N} \\
\log w_{M}=X_{M} B_{M}+\varepsilon_{M}
\end{gathered}
$$

where $w$ is gross hourly earnings, $X$ denotes human capital, job and industry characteristics, $B$ is a vector of coefficients, $\varepsilon$ is the errror term, $N$ is for natives and $M$ denotes immigrants. If 
we estimate these equations using OLS, we can write the average wage difference between natives and immigrants in, say 2006 , as:

$$
\begin{gathered}
\Delta \overline{w^{06}}=\overline{\log w_{N}^{06}}-\overline{\log w_{M}^{06}}=\beta_{N}^{06}\left(\overline{X_{N}^{06}}-\overline{X_{M}^{06}}\right)+\left(\beta_{N}^{06}-\beta_{M}^{06}\right) \overline{X_{M}^{06}} \\
=\Delta \overline{X^{06}} \beta_{N}^{06}-\overline{X_{M}^{06}} \Delta \beta^{06}=\Delta \overline{X^{06}} \beta_{N}^{06}-\overline{U_{M}^{06}}
\end{gathered}
$$

where $\Delta \overline{X^{06}}=\left(\overline{X_{N}^{06}}-\overline{X_{M}^{06}}\right), \Delta \beta^{06}=\left(\beta_{M}^{06}-\beta_{N}^{06}\right)$ and $\overline{U_{M}^{06}}=\overline{X_{M}^{06}} \Delta \beta^{06}$

Subsequently, we can write the change in the nativelimmigrant wage gap between 2006 and 2009 as:

$$
\Delta \overline{w^{09}}-\Delta \overline{w^{06}}=\left(\Delta \overline{X^{09}}-\Delta \overline{X^{06}}\right) \beta_{N}^{06}+\Delta \overline{X^{09}}\left(\beta_{N}^{09}-\beta_{N}^{06}\right)-\left(\overline{U_{M}^{09}}-\overline{U_{M}^{06}}\right)
$$

The first term in (4) measures the change in the immigrant\native wage gap between 2006 and 2009 that is due to changes in observable characteristics, the second term reflects the change in the gap that is due to changes in the returns to the observable characteristics and the third term captures the change in the residual component over time. JMP (1993) deconstruct the change in the residual component into the change due to unobserved characteristics and the change attributable to unobserved prices. To show this, we can write our wage equation for natives in 2006 as:

$$
\log w_{N}^{06}=X_{N}^{06} \beta_{N}^{06}+\sigma_{N}^{06} \theta_{N}^{06}
$$

where $\theta_{N}^{06}=\frac{V_{N}^{06}}{\sigma_{N}^{06}}$ is a standardized residual with mean zero and variance one. In a similar fashion, we can write our wage equation for immigrants in 2006 as:

$$
\log w_{M}^{06}=X_{M}^{06} \beta_{N}^{06}+\sigma_{N}^{06} \theta_{M}^{06}
$$

where $\theta_{M}^{06}=\frac{X_{M}^{06}\left(\beta_{M}^{06}-\beta_{N}^{06}\right)+V_{M}^{06}}{\sigma_{N}^{06}}$ 
Using (5) and (6), we can re-write the change in the immigrant\native wage gap between 2006 and 2009 as:

$$
\begin{aligned}
\Delta \overline{w^{09}}-\Delta \overline{w^{06}}= & \left(\Delta \overline{X^{09}}-\Delta \overline{X^{06}}\right) \beta_{N}^{06}+\Delta \overline{X^{09}}\left(\beta_{N}^{09}-\beta_{N}^{06}\right)+\left(\Delta \overline{\theta^{09}}-\Delta \overline{\theta^{06}}\right) \sigma_{N}^{06} \\
& +\Delta \overline{\theta^{09}}\left(\sigma_{N}^{09}-\sigma_{N}^{06}\right)
\end{aligned}
$$

where the third term in (7) captures the change due to unobserved characteristics and the fourth term reflects the change attributable to unobserved prices.

The decomposition allows us to separate out the impact of individual characteristics on the change in the wage gap over the period. However, there is an identification problem associated with separating out the effects of individual variables within the decomposition arising from the use of dummy variables where the number of categorical dummies exceeds one (Oaxaca and Ransom, 1999). Essentially, the change in wages attributable to differences in these types of variables might not be invariant to the choice of reference group. In such circumstances, we follow Gardeazabal and Ugidos (2004) and estimate the decompositions imposing a normalizing restriction that the coefficients must sum to zero. The implementation of this restriction leaves the other coefficients unaffected.

\subsection{Results}

Table 1 indicates that the raw immigrant \native wage gap was around 10 per cent in 2006, with the gap increasing to 29 per cent in 2009. Here, we explore the drivers of the wage disadvantage of immigrants relative to natives over time. The decomposition outlined above indicates that changes in the wage gap over time depend on differences in the endowments of wage determining characteristics of natives and immigrants, variation in the average returns to these characteristics and a residual component. We begin by examining changes in characteristics of natives and immigrants over time, as well as differences in the returns to these characteristics. We subsequently use the JMP decomposition to more formally explore 
the importance of changes in the composition and returns to specific attributes in explaining the raw immigrant \native wage gap.

\section{Differences in characteristics}

Table 2 provides some basic descriptive statistics for natives and immigrants for 2006 and 2009. Relative to natives, immigrants in 2006 are younger and have less tenure, but also have a higher level of educational attainment. There is also a higher share of immigrants working in the education sector and a smaller proportion working in public administration and defense, as compared to natives. Considering the change in immigrant characteristics over the period, we can see that a lower proportion of immigrants in 2009 have degrees, are slightly younger and have somewhat lower tenure. Unfortunately, we do not have information on the year in which immigrants arrived in Ireland. To the extent that tenure and length of time in the country are correlated, the fact that immigrants in 2009 have lower tenure on average than in 2006 might indicate that those who lost their jobs were those who had been in Ireland for a longer period. This would tend to support the notion that foreign nationals with superior characteristics have lost their jobs and/or left the country. In addition, a lower proportion of immigrants have degrees, while a smaller share of them work in the education sector. In terms of the change in native characteristics, the table shows that a higher share of native workers are degree educated in 2009, although they are slightly younger on average and have lower tenure than native workers in 2006. The large increase in the share of natives with degrees relative to the modest declines in average tenure and age might indicate that native workers with lower observable endowments have lost their jobs. Accordingly, this provides some preliminary evidence for the view that the observed rise in the unadjusted nativelimmigrant wage gap might be driven by compositional changes. 
Table 2. Descriptive statistics for natives and migrants in 2006 and 2009

\begin{tabular}{|c|c|c|c|c|c|c|c|c|}
\hline & \multicolumn{4}{|l|}{2006} & \multicolumn{4}{|l|}{2009} \\
\hline & \multicolumn{2}{|c|}{ Natives } & \multicolumn{2}{|c|}{ Immigrants } & \multicolumn{2}{|c|}{ Natives } & \multicolumn{2}{|c|}{ Immigrants } \\
\hline & Mean & Std Dev & Mean & Std Dev & Mean & Std Dev & Mean & Std Dev \\
\hline Age (in years) & 39.3 & 11.9 & 35.6 & 10.5 & 39.0 & 12.0 & 34.5 & 9.8 \\
\hline Primary & 0.07 & 0.25 & 0.04 & 0.19 & 0.07 & 0.25 & 0.07 & 0.26 \\
\hline Lower Secondary & 0.13 & 0.34 & 0.04 & 0.19 & 0.10 & 0.30 & 0.04 & 0.19 \\
\hline Upper Secondary & 0.25 & 0.43 & 0.15 & 0.35 & 0.27 & 0.44 & 0.19 & 0.39 \\
\hline Post Secondary & 0.11 & 0.31 & 0.15 & 0.36 & 0.10 & 0.30 & 0.19 & 0.39 \\
\hline Sub Degree & 0.17 & 0.37 & 0.14 & 0.35 & 0.08 & 0.28 & 0.08 & 0.27 \\
\hline Degree & 0.27 & 0.45 & 0.49 & 0.50 & 0.38 & 0.49 & 0.43 & 0.50 \\
\hline Male & 0.50 & 0.50 & 0.50 & 0.50 & 0.48 & 0.50 & 0.53 & 0.50 \\
\hline Experience (in years) & 18.3 & 11.4 & 13.5 & 10.5 & 17.6 & 11.3 & 11.8 & 9.4 \\
\hline Tenure (in years) & 10.1 & 9.4 & 6.3 & 7.8 & 9.8 & 9.0 & 4.6 & 4.1 \\
\hline Private Sector & 0.74 & 0.44 & 0.73 & 0.44 & 0.74 & 0.44 & 0.90 & 0.29 \\
\hline Permanent contract & 0.86 & 0.35 & 0.87 & 0.34 & 0.87 & 0.34 & 0.87 & 0.33 \\
\hline Fixed term contract & 0.09 & 0.28 & 0.10 & 0.30 & 0.08 & 0.27 & 0.09 & 0.28 \\
\hline Apprentice/trainee & 0.01 & 0.11 & 0.01 & 0.07 & 0.01 & 0.09 & 0.00 & 0.06 \\
\hline Other Contract & 0.04 & 0.20 & 0.03 & 0.17 & 0.04 & 0.19 & 0.04 & 0.19 \\
\hline Work fixed hours & 0.71 & 0.45 & 0.74 & 0.44 & 0.72 & 0.45 & 0.64 & 0.48 \\
\hline Shift Work & 0.23 & 0.42 & 0.31 & 0.46 & 0.20 & 0.40 & 0.37 & 0.48 \\
\hline Hours worked per month & 140.9 & 43.1 & 143.9 & 40.9 & 143.2 & 48.4 & 151.5 & 44.6 \\
\hline Union Member & 0.39 & 0.49 & 0.32 & 0.46 & 0.35 & 0.48 & 0.15 & 0.36 \\
\hline Firm Size & 3.6 & 1.8 & 3.7 & 1.8 & 3.7 & 1.8 & 3.3 & 1.6 \\
\hline Part Time & 0.15 & 0.36 & 0.10 & 0.30 & 0.23 & 0.42 & 0.18 & 0.39 \\
\hline $\begin{array}{l}\text { Member of a Professional } \\
\text { Body }\end{array}$ & 0.19 & 0.40 & 0.18 & 0.39 & 0.18 & 0.38 & 0.10 & 0.30 \\
\hline Industry & 0.17 & 0.37 & 0.17 & 0.37 & 0.15 & 0.36 & 0.17 & 0.37 \\
\hline Construction & 0.07 & 0.25 & 0.05 & 0.22 & 0.05 & 0.22 & 0.04 & 0.20 \\
\hline Wholesale \& Retail & 0.17 & 0.37 & 0.13 & 0.34 & 0.17 & 0.37 & 0.20 & 0.40 \\
\hline Hotels \& Restaurants & 0.04 & 0.19 & 0.10 & 0.30 & 0.04 & 0.19 & 0.12 & 0.32 \\
\hline Transport, Storage \& & 0.05 & 0.22 & 0.04 & 0.19 & 0.07 & 0.25 & 0.09 & 0.29 \\
\hline Communications & & & & & & & & \\
\hline Finance & 0.07 & 0.25 & 0.03 & 0.16 & 0.08 & 0.26 & 0.05 & 0.22 \\
\hline Business Services & 0.12 & 0.33 & 0.13 & 0.33 & 0.09 & 0.29 & 0.12 & 0.32 \\
\hline Pub Admin. \& Defence & 0.09 & 0.29 & 0.01 & 0.11 & 0.09 & 0.28 & 0.01 & 0.10 \\
\hline Education & 0.07 & 0.25 & 0.21 & 0.40 & 0.08 & 0.27 & 0.03 & 0.16 \\
\hline Health \& Social Work & 0.12 & 0.32 & 0.10 & 0.30 & 0.14 & 0.35 & 0.13 & 0.34 \\
\hline Other Services & 0.04 & 0.21 & 0.04 & 0.19 & 0.04 & 0.21 & 0.05 & 0.21 \\
\hline $\mathrm{N}$ & 43,947 & & 6,439 & & 57,876 & & 8,433 & \\
\hline
\end{tabular}

* Note: Firm Size: 1: 1-9 employees, 2: 10-49 employees, 3: 50-249 employees, 4: 250-499 employees, 5: 500-999 employees, 6: 1000+ employees 


\section{Differences in returns}

In addition to compositional impacts, average hourly earnings are also expected to change due to variations in the average returns to these characteristics. To investigate this, we estimate OLS log hourly wage models for 2006 and 2009, with the results presented in Table 3. The models include interaction terms to test for significant differences in the coefficients over time, while we also include a dummy variable to indicate those employees in the sample who are immigrants, ${ }^{8}$ as well as a number of controls for human capital, job characteristics and industry characteristics. The results for both 2006 and 2009 indicate that immigrants earn significantly less than comparable natives, with an estimated earnings disadvantage of 14.7 per cent in 2006. Although immigrants continue to earn less than comparable natives in 2009, the gap has narrowed somewhat, with the average earnings disadvantage at a lower 13.1 per cent. This fall in the immigrant\native wage gap could reflect evidence of an integration effect. Moreover, the results also show a rise in the returns to having a degree, while the gender pay gap also closed somewhat over the period. In terms of age groups, the estimates suggested that all age groups earn less than those aged 40 to 49 (the reference group); however, younger workers aged between 25 and 39 earned significantly less in 2009 than in 2006 . There was also an increase in the return to working for a professional body. Finally, workers in industry and public administration and defense earned significantly more in 2009 than in 2006, while workers in construction and education earned significantly less.

The wage disadvantage for immigrants is likely to hide differences across different types of immigrants. To explore this, we run the OLS wage models including separate dummies indicating the region that the immigrant is from, with the results shown in Table 4 . The estimates indicate that earnings for migrants from the UK are not significantly different to comparable natives in either year. Employees from the NMS experience the highest wage

\footnotetext{
${ }^{8}$ The immigrant dummy variable is equal to one for all employees whose response to a question on nationality was anything other than 'Irish'. Those who do not report their nationality are excluded from our sample.
} 
disadvantage, and despite no significant change in the earnings gap for EU-10 immigrants, there is a fall in the earnings gap for EU-2 immigrants over the period (significant at the 10 per cent level). The results also show a large fall in the wage gap for immigrants from EU-15 countries (excluding UK and Ireland). Finally, there is an increase in the wage disadvantage for immigrants from non-EU English speaking countries, while the wage gap for employees from non-EU non-English speaking countries fell slightly.

Separate wage models were also run for employees in the private and public sector. ${ }^{9}$ The results indicate that there was no significant change in the wage disadvantage for immigrants in the private sector, earning 15 per cent and 13.8 per cent less than comparable natives in 2006 and 2009 respectively. However, there was a significant fall in the wage disadvantage for immigrants in the public sector, where the estimate falls from 15 per cent in 2006 to 4.8 per cent in 2009.

\footnotetext{
${ }^{9}$ The results are available from the Authors on request. The models include the same controls as those in Table 3.
} 
Table 3. OLS wage models

\begin{tabular}{|c|c|c|c|}
\hline & 2006 & 2009 & Difference \\
\hline Migrant & $-0.147 * * *$ & $-0.131 * * *$ & $0.016 * *$ \\
\hline \multicolumn{4}{|l|}{ Education (Ref: Primary or Less) } \\
\hline Lower Secondary & $0.056 * * *$ & $0.055^{* * *}$ & -0.002 \\
\hline Upper Secondary & $0.161 * * *$ & $0.140 * * *$ & $-0.020 * *$ \\
\hline Post Secondary & $0.192 * * *$ & $0.161 * * *$ & $-0.031 * * *$ \\
\hline Cert/Diploma & $0.264 * * *$ & $0.248 * * *$ & -0.015 \\
\hline Degree & $0.449 * * *$ & $0.469 * * *$ & $0.020 * *$ \\
\hline Male & $0.153 * * *$ & $0.138 * * *$ & $-0.015 * * *$ \\
\hline Tenure & $0.012 * * *$ & $0.012 * * *$ & -0.000 \\
\hline \multicolumn{4}{|l|}{ Age (Ref: Age 40-49) } \\
\hline Age 15 to 24 & $-0.299 * * *$ & $-0.271 * * *$ & $0.029 * * *$ \\
\hline Age 25 to 29 & $-0.143 * * *$ & $-0.176 * * *$ & $-0.033 * * *$ \\
\hline Age 30 to 39 & $-0.014 * *$ & $-0.035 * * *$ & $-0.022 * * *$ \\
\hline Age 50 to 59 & $-0.027 * * *$ & $-0.039 * * *$ & -0.011 \\
\hline Age 60 plus & $-0.112 * * *$ & $-0.074 * * *$ & $0.038 * * *$ \\
\hline \multicolumn{4}{|l|}{ Employment Contract (Ref: } \\
\hline Fixed Term Contract & $-0.047 * * *$ & $-0.040 * * *$ & 0.007 \\
\hline Apprentice/trainee & $-0.315^{* * *}$ & $-0.278 * * *$ & $0.037 *$ \\
\hline Other Contract & $-0.043 * * *$ & $-0.035 * * *$ & 0.008 \\
\hline Fixed Hours & $-0.021 * * *$ & $-0.025 * * *$ & -0.004 \\
\hline Shift Work & $-0.035 * * *$ & $-0.036 * * *$ & -0.000 \\
\hline Firm Size & $0.036 * * *$ & $0.040 * * *$ & $0.004 * * *$ \\
\hline Part Time & $-0.139 * * *$ & $-0.128 * * *$ & $0.011^{*}$ \\
\hline Member of a Professional Body & $0.112 * * *$ & $0.187 * * *$ & $0.075 * * *$ \\
\hline Union Member & $0.024 * * *$ & $0.023 * * *$ & -0.001 \\
\hline \multicolumn{4}{|l|}{ Sector (Ref: Hotels \& Restaurants) } \\
\hline Industry & $0.087 * * *$ & $0.115^{* * *}$ & $0.028 * *$ \\
\hline Construction & $0.271 * * *$ & $0.227^{* * *}$ & $-0.043 * * *$ \\
\hline Wholesale \& Retail & $0.049 * * *$ & $0.068 * * *$ & $0.019 *$ \\
\hline Transport, Storage \& & $0.122 * * *$ & $0.101 * * *$ & -0.021 \\
\hline Finance & $0.219 * * *$ & $0.234 * * *$ & 0.015 \\
\hline Business Services & $0.096 * * *$ & $0.098 * * *$ & 0.002 \\
\hline Public Admin \& Defence & $0.136 * * *$ & $0.192 * * *$ & $0.057 * * *$ \\
\hline Education & $0.420 * * *$ & $0.359 * * *$ & $-0.061 * * *$ \\
\hline Health \& Social Work & $0.199 * * *$ & $0.191 * * *$ & -0.008 \\
\hline Other Services & $0.089 * * *$ & $0.121 * * *$ & $0.032 * *$ \\
\hline Constant & $2.266 * * *$ & $2.323 * * *$ & $0.025^{* * *}$ \\
\hline $\mathrm{N}$ & 50,130 & 66,122 & \\
\hline R-squared & 0.437 & 0.468 & \\
\hline
\end{tabular}

Note: ${ }^{* * *} p<0.01,{ }^{* *} p<0.05,{ }^{*} p<0.1$ 
Table 4. OLS wage models with immigrant variable broken out

\begin{tabular}{|l|lll|}
\hline & 2006 & 2009 & Difference \\
\hline Migrant: & & & \\
UK & 0.018 & 0.001 & -0.017 \\
EU 15 excluding UK \& Ireland & $-0.173^{* * *}$ & $-0.083^{* * *}$ & $0.089^{* * *}$ \\
EU-10 (2004 enlargement) & $-0.224^{* * *}$ & $-0.209^{* * *}$ & 0.015 \\
EU-2 (2007 enlargement) & $-0.207^{* * *}$ & $-0.127^{* * *}$ & $0.080^{*}$ \\
Non-EU/English Speaking & $-0.075^{* * *}$ & $-0.141^{* * *}$ & $-0.066^{*}$ \\
Non-EU/Non-English Speaking & $-0.162^{* * *}$ & $-0.138^{* * *}$ & $0.025^{*}$ \\
\hline
\end{tabular}

Note: ${ }^{* * *} p<0.01,{ }^{* *} p<0.05,{ }^{*} p<0.1$. The same regressors as those in Table 2 are also included in the models presented in Table 3.

\section{Decomposition analysis}

The descriptive data indicates that immigrant earnings fell by over 8 per cent between 2006 and 2009, while the earnings of natives increased by over 7 per cent in the same period. Furthermore, the descriptive statistics also show that wage falls were exclusive to non-EU immigrants. These wage movements translated into a rise in the unadjusted $\backslash$ raw immigrant wage penalty from 10 per cent in 2006 to 29 per cent in 2009 . However, care must be taken when interpreting such data, given that the observed increase in the immigrant penalty can be driven by either a higher concentration of lower skilled workers within the immigrant population in Ireland (an endowment effect) and/or a deterioration in rates of return to wage determining characteristics among immigrants relative to their native counterparts (a coefficient effect).

Separate Oaxaca decompositions ${ }^{10}$ for the raw immigrant wage gap in 2006 and 2009 indicate that around -50 per cent of the immigrant wage gap in 2006 was attributable to changes in characteristics, suggesting that immigrants had superior endowments to natives, while 150 per cent of the immigrant wage gap was attributable to coefficient effects. However, by 2009 , approximately 50 per cent of the immigrant wage disadvantage related to differences in the characteristic make up between immigrants and natives (and only 33 per cent was attributable to coefficient effects), suggesting that substantial changes took place in the

\footnotetext{
${ }^{10}$ The results of the Oaxaca decompositions are available from the Authors.
} 
characteristic make up of either the immigrant or native employee populations during this period.

In order to determine the source of the deterioration in the unadjusted immigrant/native wage gap over time, we estimate a John Murphy Peirce (JMP) decomposition, ${ }^{11}$ with the results presented in Table E. Based on the model coefficients, the JMP approach predicts that the raw immigrant wage differential widened by 17 per cent points between 2006 and $2009^{12}$ with most of this change attributable to observable effects; the change in the predicted gap or the change due to observable characteristics and returns to these characteristics was 19 per cent, while the change in the residual gap was - 2 per cent. Specifically, just under 30 per cent of the growth in the predicted differential (19 per cent) was due to a fall in the share of graduates within the immigrant population, while a further 26 per cent of the decline resulted from a fall in the number of immigrants employed within relatively well-paid public sector occupations (Table E).

It is important to note that the JMP technique extends the Oaxaca Blinder approach by decomposing the gap, not just at the mean but also across the entire distribution, thus taking account of the residual (unexplained) distribution. Therefore, the JMP approach explicitly introduces the price of unobserved skills (measured by the standard deviation of the residuals) into the decomposition. However, the JMP technique has been criticized on the basis that its extensions are underpinned by two strong assumptions that are difficult to verify: (a) that the OLS estimates of one group are not biased while those of the other group are biased, and thus only the coefficients of the unbiased group enter the model; and, stemming from this; and (b) that discrimination is stable over time ${ }^{13}$ (Suen, 1997; Yun, 2007). Nevertheless, the JMP approach is favored on the grounds that it explicitly incorporates the return to unobservable

\footnotetext{
${ }^{11}$ The JMP technique is reviewed in (Fortin et al., 2011).

12 This aligns closely with the descriptive results.

${ }^{13}$ This is by virtue of the fact that the technique does not explicitly incorporate a discrimination measure based on the between group difference in the price coefficients.
} 
skills, which is particularly relevant when comparing migrants and natives. Furthermore, the results indicate that much of the change in the gap is due to endowment effects, implying that changes in discrimination are likely to be unimportant. 
Table E. Juhn-Murphy Pierce decomposition of the change in the immigrant wage gap between 2006 and 2009

\begin{tabular}{|l|l|l|}
\hline Change in the log wage differential & & 0.1723 \\
$\begin{array}{l}\text { Observables: (Decomposition of Change in Predicted Gap) } \\
\text { Endowment Effect }\end{array}$ & & 0.1929 \\
$\quad$ & 0.1774 \\
$\quad$ Of which: & 0.0538 & \\
$\quad$ Degrees & 0.0499 & \\
$\quad$ Public Sector Occupations & 0.0154 \\
Price Effect & & \\
Unobservables: (Decomposition of Change in Residual Gap) & & -0.0206 \\
Endowment Effect & -0.0161 \\
Price Effect & -0.0046 \\
\hline
\end{tabular}

In order to pinpoint the source of the endowment effects driving the rise in the unadjusted immigrant wage disadvantage, we estimate JMP models for both the public and private sectors and for each immigrant grouping. ${ }^{14}$ While the predicted raw immigrant wage penalty increased in both the public and private sectors, there were substantial differences in the scale of the effect across both industries. Within the private sector, the predicted raw immigrant wage penalty increased by 2.9 percentage points between 2006 and 2009, and again most of this is attributable to changes in observable effects. The change in the predicted gap is explained by endowment and coefficient impacts in almost equal measures. With respect to private sector endowment impacts, these were dominated by falls in the employment share of graduates, resulting in a rise in the immigrant pay differential of 2.1 percentage points. Within the public sector, the predicted raw immigrant wage gap increased by a remarkable 20 percentage points over the period, with all of the movement explained by changes in the composition of the immigrant workforce. The bulk of the change in the predicted public sector immigrant pay disadvantage can be explained by declines in the following among the population of publically employed immigrants: (a) the level of

\footnotetext{
${ }^{14}$ Detailed results available from the authors.
} 
employment within the education sector (38\%); (b) the number of graduates (27\%); and (c) the average level of worker tenure (19\%).

Finally, with respect to the relative effects across immigrant groupings, in line with the descriptive data, we found that immigrants from non-EU non-English speaking countries experienced the most substantial deterioration over the period. Between 2006 and 2009, the predicted raw pay differential of immigrants from non-EU non-English speaking countries employed within all sectors of the economy increased by 36 percentage points relative to their native counterparts. Again, the entire decline in the wage position of this immigrant group was attributable to composition influences related to a fall in the number of graduates and workers employed within the education sector. Moreover, a fall in average tenure levels and decline in the number of persons employed in large firms also contributed to a decline in relative wages.

From the data, it is not possible to discern the exact reasons underlying the changes observed within the immigrant wage penalty; nevertheless, by 2009 , the impacts of the fiscal crises were being fully felt, with substantial pressure placed on public sector organizations to cut costs. The industrial relations framework in Ireland precluded the widespread use of redundancy as a cost control mechanism; however, it is likely that departments sought to lower wage costs through the non-renewal of fixed term or temporary contracts, and presumably such policies disproportionately effecting graduate immigrants from non-EU nonEnglish speaking countries.

To summarize, the raw data shows a large increase in the immigrant wage penalty over the crisis period. However, when we control for relevant characteristics, the OLS results indicate that the immigrant wage penalty fell slightly over the period, which could point to an integration effect in the labor market. Unfortunately, our dataset does not contain information on the date of arrival; however, the data shows that average tenure has fallen among immigrants, and thus to the extent that tenure and length of stay are correlated, the fall in the 
wage penalty is unlikely to reflect an integration effect. Furthermore, our results also show differences in the immigrant penalty across different migrant groups. For example, immigrants from the NMS experience the largest overall pay penalty and the gap for EU-10 immigrants remains unchanged, while the gap for EU-2 immigrants narrows over the period. In addition, we find a large fall in the penalty for EU 15 immigrants (excluding UK and Ireland). The decomposition results show that compositional changes are driving the change in the raw immigrant wage penalty. In particular, a fall in the share of immigrants with degrees and those in the relatively well-paid public sector occupations explain a substantial part of the change in the wage gap.

\section{Conclusions}

Ireland's economic and migratory experiences have been dramatic over the last fifteen to twenty years. The economic boom provided a remarkable period of growth, which led to a reversal of Ireland's traditional pattern of outward migration. The rate of inflow was large and produced something of a transformation in the make-up of the Irish population. For example, in the four-year period from 2002 to 2006 , the proportion of Ireland's population that was non-Irish grew from 7 per cent to 11 per cent (Barrett, 2010). The economic collapse has led to the resumption of net out-flows, with both Irish people and immigrants contributing.

Based upon these movements, Ireland has provided an interesting new case study for migration research. Many of the findings on Ireland's immigrants that were produced during the boom mirrored results that had been found elsewhere. For example, immigrants earned less compared to natives and were found to have had a positive effect on economic growth. Other research findings showed differences between Ireland and elsewhere, as exemplified by the finding that immigrants were less likely to receive welfare support.

The economic collapse was more severe in Ireland relative to elsewhere. Many questions have arisen concerning the impacts of the collapse, including the impacts of 
immigrants and their subsequent reactions. Earlier research showed that immigrant employment contracted sharply over the recession, thereby suggesting reduced demand for immigrant labor. In this chapter, we have expanded the analysis of the impacts of the recession on immigrants by asking whether their earnings also fell, relative to natives. Although the raw data shows a widening of the immigrant/native pay gap, a decomposition analysis shows that most of this was generated by the changing composition of the immigrants who were employed.

Both the immigrant and native population in Ireland are now reacting to the downturn, to an extent, through out-migration. Net outflows from Ireland resumed in 2010 and it is estimated (by the Central Statistics Office) that almost 90,000 people (net) left Ireland in the three-year period ending April 2012, representing around 2 per cent of the 2010 population. As discussed above, the rate of net outflow is higher for EU NMS immigrants in particular. For this reason, Ireland seems to be benefiting from a relatively mobile labor force, which flowed in during the boom and is flowing out during the downturn. This renders the Irish situation somewhat different to elsewhere, where less subsequent mobility of immigrant populations is observed. The mobility observed in Ireland might have reflected a function of the fact that many immigrants arrived in the years leading up to the downturn and thus might not have had time to become rooted in Ireland. Alternatively, the fact that the Irish government restricted welfare to immigrants might have reduced the incentive to stay (Barrett, 2013). Either way, flows to and from Ireland will continue to provide interesting insights into migratory mechanisms and their effects. 


\section{References}

Addison-Smyth D, and K. McQuinn (2010), "Quantifying Revenue Windfalls from the Irish Housing Market", Economic and Social Review, 41(2).

Barrett, A. (2010), “EU Enlargement and Ireland's Labour Market", in M. Kahanec and K.F. Zimmermann (eds.), EU Labor Markets after Post-Enlargement Migration, Berlin: Springer.

Barrett, A., A. Bergin and D. Duffy (2006), "The Labour Market Characteristics and Labour Market Impacts of Immigrants in Ireland", Economic and Social Review, 37(1).

Barrett, A. and D. Duffy (2008), "Are Ireland's Immigrants Integrating into its Labour Market?", International Migration Review, 42(3).

Barrett, A., C. Joyce and B. Maïtre (2013), "Immigrants and Welfare Receipt in Ireland", International Journal of Manpower, 34(1/2), pp. 142-154.

Barrett, A. and E. Kelly (2012), "The Impact of Ireland's Recession on the Labour Market Outcomes of its Immigrants", European Journal of Population, 28(1), pp. 99-111.

Barrett, A. and Y. McCarthy (2007), "Immigrants in a Booming Economy: Analysing their Earnings and Welfare Dependence", LABOUR: Review of Labour Economics and Industrial Relations, 21(4-5).

Barrett, A. and Y. McCarthy (2008), "Immigrants and Welfare Programmes: Exploring the Interactions between Immigrant Characteristics, Immigrant Welfare Dependence and Welfare Policy", Oxford Review of Economic Policy, 24(3).

Barrett, A., S. McGuinness and M. O’Brien (2012), “The Immigrant Earnings Disadvantage across the Earnings and Skills Distributions: The Case of Immigrants for the EU's New Member States", British Journal of Industrial Relations, 50(3), pp. 457-481. 
Bergin, A., E. Kelly and S. McGuiness (2012), "Explaining Changes in Earnings and Labour Costs During the Recession", ESRI Renewal Series 009.

Fortin, N., T. Lemieux and S. Firpo (2011), "Decomposition Methods in Economics", Handbook of Labor Economics, Elsevier.

Gardeazabal, J. and A. Ugidos (2004), “More on Identification in Detailed Wage

Decompositions", The Review of Economics and Statistics, 86(4), pp. 1034-6.

Juhn, C., K.M. Murphy and B. Pierce (1993), "Wage Inequality and the Rise in Returns to Skill", Journal of Political Economy, 101(3), pp. 410-442.

Oaxaxa, R. and M. Ransom (1999), "Identification in Detailed Wage Decompositions", The Review of Economics and Statistics, 81(1), pp. 154-157.

Suen, W. (1997), "Decomposing Wage Residuals: Unmeasured Skill or Statistical Artifact?" Journal of Labor Economics, 15(3), pp. 555-566.

Walsh, F. (forthcoming), "Labour Market Regulation and Migration in Ireland", Economic and Social Review, 44(1).

Yun, M. (2007), "Wage Differentials, Discrimination and Inequality: A Cautionary Note on the Juhn, Murphy and Pierce Decomposition Method", IZA Discussion Papers 2937, Institute for the Study of Labor (IZA). 